\title{
Paul-Henri Thiry d'Holbach: Razkrito krščanstvo ali pregled načel in učinkov krščanske religije
}

\author{
Ljubljana: Krtina, 2011, 148 strani
}

Delo, ki smo ga nedavno dobili v slovenskem prevodu, sodi na področje obravnave religije in se ukvarja predvsem z vprašanjem, kakšen je pomen te družbene institucije za posameznike in družbo kot celoto. Kot je zapisano v samem naslovu, se pričujoče delo osredotoča na pregled načel krščanske religije, ki je prvenstveno zaznamovala evropski prostor, ter skuša na ta način odgovoriti na vedno znova aktualno vprašanje, ali je ta za posameznika in družbo sploh potrebna. Rezultat tako zastavljene problematike je krščanstvo, ki je do golega razkrito, in sicer tako, da lahko vsak zlahka ugotovi, da so njegovi učinki nični, če ne celo škodljivi. Avtor dela izhaja iz obdobja razsvetljenstva in tako je tudi njegova študija predvsem odraz tedanjega časa. Zato je za sodobnega slovenskega raziskovalca načel in učinkov (krščanske) religije zelo zanimiva in dobrodošla pridobitev, saj ima možnost vpogleda $\mathrm{v}$ čas rojevanja sekularizacije in zlasti njenega (prvotnega) razumevanja religije kot negativnega družbenega pojava, ki se bo sčasoma umaknil pohodu razuma in znanosti.

Knjiga je sestavljena iz predgovora ter šestnajstih krajših poglavij. Predgovor je zastavljen kot avtorjevo pismo, v katerem odgovarja na pripombe na svoje delo. Bralec lahko že uvodoma razbere ton, v katerem je delo napisano, ter njegove glavne ugotovitve: krščanstvo se kaže zlasti kot skupek neumnosti, neskladnosti, nesmiselnih naukov ter otročjega obredja in idej, ki so sposojene od drugih religijskih sistemov, $\mathrm{s}$ katerimi je $\mathrm{v}$ svoji zgodovini pač prihajalo $\mathrm{v}$ neposreden stik. $\mathrm{V}$ predgovoru lahko tudi že stopimo $\mathrm{v}$ stik $\mathrm{z}$ glavnim razsvetljenskim argumentom dela, ki je vprašanje ločitve cerkve in države, predvsem na področju morale, kjer mora v ospredje stopiti politična morala, ki se napaja pri napredku človeškega duha in kjer je vse podvrženo samo razumu.

$\mathrm{V}$ nadaljevanju avtor ugotovi, da je religioznost posameznikov zgolj rezultat tradicije in navade. Ker pa se religija kaže kot najpomembnejša zadeva, ki posega tako v naše tostransko življenje kot tudi zasmrtje, je njeno preučevanje neizogibno. Takoj ko se začnemo s tem družbenim pojavom znanstveno ukvarjati, pa lahko hitro ugotovimo različna neskladja, ki glede religije ne morejo voditi do drugačnega sklepa kot le, da je družbeno nekoristna. Razkrivanja tančice krščanstva se avtor loti 
na začetku, to je pri judovstvu, iz katerega je krščanstvo pravzaprav izšlo. Judovsko religijo predstavi kot kruto in smešno praznoverje. Za Hebrejce tako trdi, da so bili nasilno in morilsko ljudstvo, ki se je slepo pokoravalo duhovščini, njihova zgodovina pa je polna nasilnih pohodov, ki niso prizanašali nikomur. Iz takega okolja torej izhaja krščanstvo, ki je pravi predmet obravnave. Kot glavni dokaz, da je ta religiozni sistem brezobličen in nepovezan, avtor izpostavi dejstvo, da ni bil sprejet niti med samimi Judi. Sprejeli so ga le najbolj zavrženi, tisti na obrobju tedanje družbe. S takimi ljudmi pa se je po avtorjevem prepričanju tudi edinole dalo manipulirati, da so tem idejam tudi res sledili. Brž ko je krščanstvo postalo močno, je strašnega judovskega boga le še bolj stopnjevalo ter v svoj religiozni sistem vneslo še več pretiravanja.

Avtor pričujočega dela ne prizanese ničemur in njegove kritične obravnave je deležno vse po vrsti: ustavi se pri krščanski mitologiji oziroma krščanskih idejah o bogu in njegovem vedenju, razodetju, čudežih, prerokbah, mučencih, skrivnostih krščanske religije, verskih resnicah, obredih, svetih knjigah kristjanov, krščanski morali, vrlinah, izpolnjevanju obredij in dolžnostih krščanske religije, njenih političnih posledicah ter nenazadnje tudi pri sami cerkvi oziroma duhovščini. To so hkrati tudi naslovi razmeroma kratkih poglavij, v katerih poskuša avtor nenavadno hitro in jedrnato ovreči celoten religijski sistem, kar samo po sebi govori, da se lahko njegovi argumenti sodobnemu bralcu na trenutke kažejo precej trivialni, saj se avtor ne spušča v nikakršne razprave, ko sledi le enemu cilju - pokazati nesmiselnost in škodljivost krščanstva za družbeni red evropske družbe. Nekoliko strnjeno bi zato njegova dognanja opisali takole: krščanski bog se kaže vse prej kot dober. V krščanski mitologiji, kot jo lahko spoznamo iz Biblije, srečamo boga, ki ga menjaje vodita ljubezen in jeza, maščevanje in usmiljenje. Skratka, to je bog, ki deluje po načelu »vroče - hladno«, kar kaže na njegovo samovoljo. Na ta način sama podoba takega boga ne ponuja temelja, na katerem bi lahko osnovali pravičnost. $\mathrm{V}$ tem kontekstu se ponovno odpira vprašanje trpljenja in zla v svetu. Ena izmed glavnih preokupacij avtorja pričujočega dela je tudi vprašanje, kako lahko brez pomoči razuma vemo, da bog res obstaja. Gre skratka za spraševanje po dokazih o obstoju boga in njihovi verodostojnosti. V krščanski religiji je vse skrivnostno, nejasno, negotovo in sporno. Biblijo vsakdo razume in interpretira po svoje, vse je prepuščeno domišljiji ter samovoljnim odločitvam duhovnikov. Dalje, tudi dokazi, ki govorijo krščanski religiji v prid, posameznikom in družbi ne pomagajo, da bi bili boljši. Čudeže, prerokbe in mučence poznajo tudi druge religije, spet pa se je vredno vprašati, kdo so bile priče čudežev, kdo sploh so bili preroki in mučenci. Vse namreč kaže na to, da je šlo za dobre manipulatorje, ki so se osredotočali le na neuko ljudstvo. Nauki, skrivnosti in verske resnice krščanstva pa so sploh dvoumni in razumu nedostopni, ljudem pa prinašajo le stvari, ki vzbujajo strah in grozo. Avtor napada tudi obredje in slovesnosti, ki jim očita nerazumljiv in skrivnosten ton. Za 
zakramente meni, da so neresni in smešni obredi, v katerih vidi predvsem magična dejanja. Polna protislovij so tudi verska besedila, ki ne morejo ponuditi nobene prave predstave o bogu, še več, tudi najbolj nasprotne strani lahko v njih najdejo argumente za svoje početje, ki ga nato še opravičujejo, češ da to počnejo v imenu boga.

Vrhunec dela gotovo predstavlja razprava o krščanski morali. Glede na vsa predhodno razkrita krščanska načela avtor ugotavlja, da je nemogoče osnovati moralo na takem bogu ali takih knjigah, ki vsebujejo protislovne zakone, saj na ta način družba le daje podlago muhavosti tistih, ki govorijo v imenu boga. V ospredje tako pride tudi razprava o duhovščini, ki zase trdi, da je nezmotljiva, od posameznikov pa zahteva podložnost, darežljivost in ponižnost ter uči sprejemanje danega družbenega položaja. Popolnoma zatira mišljenje ter ima odkrite pretenzije po posvetni oblasti. V tem kontekstu se torej vrši višek dela, ko avtor odkrito spregovori o samih političnih posledicah krščanstva. Na tem mestu zaostri odnos med državo in cerkvijo, posvetno in sveto oblastjo, religiozno in politično moralo. Avtor izrecno zahteva ločitev med njima ter meni, da bi morala biti morala utemeljena izključno na vladarjevem dobrem zgledu, ki se opira na razum. V tem lahko spoznamo korenine sekularizacijske teze.

D'Holbachovo delo Razkrito krščanstvo ali pregled načel in učinkov krščanske religije je zanimivo branje z vsaj treh perspektiv. Kot prvo bi lahko izpostavili priložnost vpogleda v razsvetljensko doumevanje sveta, kjer so se zavzemali predvsem za takšno družbeno realnost, ki bi odgovarjala primatu razuma. Prvo oviro so pri takem razumevanju razumljivo srečali najprej v religiji. To je čas, ko se evropska družba šele loteva procesa odčaranja sveta. Pričujoče delo predstavlja slovenskemu bralcu odlično možnost vpogleda $\mathrm{v}$ same začetke sekularizacije in prvih argumentov, ki govorijo v njeno korist. Odveč bi bilo na tem mestu dokazovati, da je glavna d'Holbachova zahteva po ločitvi religioznega od političnega danes tudi res postala aksiom vsakega vzpostavljanja moderne države, njenih institucij ter družbenih odnosov med ljudmi. $\mathrm{V}$ tem lahko prepoznamo drugo perspektivo razmišljanja o opisani tematiki. Tretja pa je branje dela, ki nas napotuje na problematiko razumevanja religije in religioznega danes. Vedno znova aktualno vprašanje vloge religije v evropski družbi je tudi danes predmet številnih študij, ki pa se problema lotevajo z drugačnega zornega kota, kot je predstavljen v pričujočem delu. Če sprejmemo predpostavko, da je religija kot institucija ločena od političnega, še ne pomeni, da je za posameznika nepotrebna. Nove poti, v katere se razvija sveto danes, so raznolike. D'Holbach je v svojem delu tako odprl problematiko, ki je težko razrešljiva in ki se danes razvija v takšne oblike, ki so bile v njegovem času še neslutene. 